s completely to $\mathrm{CO}_{2}$. Materials research on proton and oxygen ion conductors in the past decade shows that such fuel cells are possible.

For intermediate-temperature hybrid fuel cells to become a reality, researchers need to create solid electrolytes with high

conductivity, and find electrode materials that have high activity and stability and that react with methane without forming coke (solid carbon). These devices must use less platinum catalyst and more impure fuel than low-temperature polymer cells; make do with cheaper seals and connectors; and last longer than highertemperature solid-oxide fuel cells.

US researchers have made a start. I launched the Reliable Electricity Based on Electrochemical Systems (REBELS) programme at ARPA-E with $\$ 33$ million in funding in June 2014. It is starting to bear fruit $^{10}$. Efforts elsewhere, particularly in Europe and Japan, are addressing hydrogen generation and GTL separately but could also benefit from hybrid fuel cells.

Researchers should prove the viability of intermediate-temperature fuel cells with these extra functions by demonstrating high power density and a lifetime of ten years, compared with current cell lifetimes of less than five. Cost savings must be validated through rigorous techno-economic modelling. Advances will then need to be scaled up from individual cells to kilowattscale systems, which will take 5-10 years.

Regulators, utility companies, technologists and users must define an appropriate mix of technologies and incentives to maintain the stability of the electricity grid in the coming decades. Hybrid fuel cells must be part of that conversation.

John P. Lemmon is a programme director at the US Department of Energy Advanced Research Projects Agency-Energy (ARPA-E), Washington DC, USA. e-mail:john.lemmon@hq.doe.gov

1. Schröder, C. Der Spiegel 'Energy Revolution Hiccups: Grid Instability Has Industry Scrambling for Solutions' (16 August 2012)

2. US Energy Information Administration. Modeling Distributed Generation in the Building Sectors (EIA, 2013).

3. Federal Energy Regulatory Commission. Assessment of Demand Response and Advanced Metering (2012).

4. Lew, D. et al. The Western Wind and Solar Integration Study Phase 2 (US Natl Renewable Energy Lab., 2013).

5. Weiss, J. \& Tsuchida, B. Integrating Renewable Energy into the Electricity Grid (Brattle Group, 2015).

6. Chartouni, D., Kuriyama, N., Kiyobayahsi, T. \& Chen, J. Int. J. Hydrogen Energy 27, 945-952 (2002).

7. Wang, C., Appleby, A. J., Cocke, D. L. J. Electrochem. Soc. 151, A260-A264 (2004).

8. Van Overmeere, Q., Kerman, K. \& Ramanathan, S. Nano Lett. 12, 3756-3760 (2012).

9. Jacobs, T. J. Pet. Technol. 65, 4135 (2013).

10.Duan, C. et al. Science http://dx.doi.org/ 10.1126/science.aab3987 (2015).

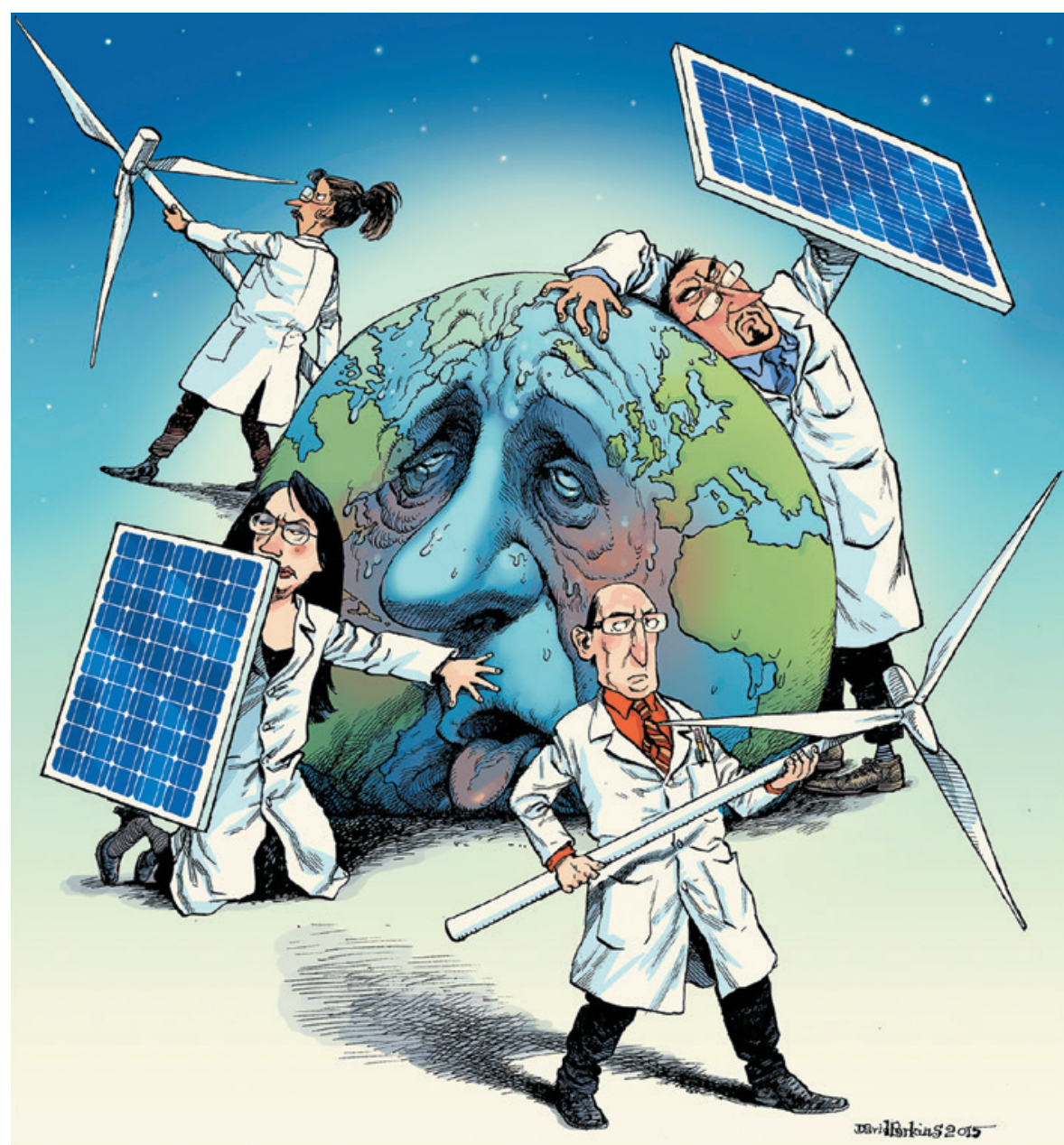

\title{
Democracy is not an inconvenience
}

\section{Climate scientists are tiring of governance that does not} lead to action. But democracy must not be weakened in the fight against global warming, warns Nico Stehr.

$\mathrm{T}$ here are many threats to democracy in the modern era. Not least is the risk posed by the widespread public feeling that politicians are not listening. Such discontent can be seen in the political far right: the Tea Party movement in the United States, the UK Independence Party, the Pegida (Patriotic Europeans Against the Islamization of the West) demonstrators in Germany, and the National Front in France.

More surprisingly, a similar impatience with the political elite is now also present in the scientific community. Researchers are increasingly concerned that no one is listening to their diagnosis of the dangers of human-induced climate change and its long-lasting consequences, despite the robust scientific consensus. As governments continue to fail to take appropriate political action, democracy begins to look to some like an inconvenient form of governance. There is a tendency to want to take decisions out of the hands of politicians and the public, and, given the 'exceptional circumstances', put the decisions into the hands of scientists themselves.

This scientific disenchantment with democracy has slipped under the radar of many social scientists and commentators. Attention is urgently needed: 
v the solution to the intractable 'wicked problem' of global warming is to enhance democracy, not jettison it.

\section{VOICES OF DISCONTENT}

Democratic nations seem to have failed us in the climate arena so far. The past decade's climate summits in Copenhagen, Cancun, Durban and Warsaw were political washouts. Expectations for the next meeting in Paris this December are low.

Academics increasingly point to democracy as a reason for failure. NASA climate researcher James Hansen was quoted in 2009 in The Guardian as saying: "the democratic process doesn't quite seem to be working"' In a special issue of the journal Environmental Politics in 2010, political scientist Mark Beeson argued ${ }^{2}$ that forms of 'good' authoritarianism "may become not only justifiable, but essential for the survival of humanity in anything approaching a civilised form". The title of an opinion piece published earlier this year in The Conversation, an online magazine funded by universities, sums up the issue: 'Hidden crisis of liberal democracy creates climate change paralysis' (see go.nature.com/pqgysr).

The depiction of contemporary democracies as ill-equipped to deal with climate change comes from a range of considerations. These include a deep-seated pessimism about the psychological make-up of humans; the disinclination of people to mobilize on issues that seem far removed; and the presumed lack of intellectual competence of people to grasp complex issues. On top of these there is the presumed scientific illiteracy of most politicians and the electorate; the inability of governments locked into short-term voting cycles to address long-term problems; the influence of vested interests on political agendas; the addiction to fossil fuels; and the feeling among the climate-science community that its message falls on the deaf ears of politicians.

Such views can be heard from the highest ranks of climate science. Hans Joachim Schellnhuber, founding director of the Potsdam Institute for Climate Impact Research and chair of the German Advisory Council on Global Change, said of the inaction in a 2011 interview with German newspaper Der Spiegel: "comfort and ignorance are the biggest flaws of human character. This is a potentially deadly mix".

What, then, is the alternative? The solution hinted at by many people leans towards a technocracy, in which decisions are made by those with technical knowledge. This can be seen in a shift in the statements of some co-authors of Intergovernmental Panel on Climate Change reports, who are moving away from a purely advisory role towards policy prescription (see, for example, ref. 3).

We must be careful what we wish for. Nations that have followed the path of 'authoritarian modernization', such as China and Russia, cannot claim to have a record of environmental accomplishments. In the past two or three years, China's system has made it a global leader in renewables (it accounts for more than one-quarter of the planet's investment in such energies $\left.{ }^{4}\right)$. Despite this, it is struggling to meet ambitious environmental targets and will continue to lead the world for some time in greenhouse-gas emissions. As Chinese citizens become wealthier and more educated, they will surely push for more democratic inclusion in environmental policymaking.

Broad-based support for environmental concerns and subsequent regulations came about in open democratic argument on the value of nature for humanity. Democracies learn from mistakes; autocracies lack flexibility and adaptability ${ }^{5}$.

"It is dangerous to blindly believe that science and scientists alone can tell us what to do."

\section{Democratic nations}

have forged the most effective international agreements, such as the Montreal Protocol against ozone-depleting substances.

\section{GLOBAL STAGE}

Impatient scientists often privilege hegemonic players such as world powers, states, transnational organizations, and multinational corporations. They tend to prefer sweeping policies of global mitigation over messier approaches of local adaptation; for them, global knowledge triumphs over local know-how. But societal trends are going in the opposite direction. The ability of large institutions to impose their will on citizens is declining. People are mobilizing around local concerns and efforts ${ }^{6}$.

The pessimistic assessment of the ability of democratic governance to cope with and control exceptional circumstances is linked to an optimistic assessment of the potential of large-scale social and economic planning. The uncertainties of social, political and economic events are treated as minor obstacles that can be overcome easily by implementing policies that experts prescribe. But humanity's capacity to plan ahead effectively is limited. The centralized social and economic planning concept, widely discussed decades ago, has rightly fallen into disrepute ${ }^{7}$.

The argument for an authoritarian political approach concentrates on a single effect that governance ought to achieve: a reduction of greenhouse-gas emissions. By focusing on that goal, rather than on the economic and social conditions that go hand-in-hand with it, climate policies are reduced to scientific or technical issues. But these are not the sole considerations. Environmental concerns are tightly entangled with other political, economic and cultural issues that both broaden the questions at hand and open up different ways of approaching it. Scientific knowledge is neither immediately performative nor persuasive.

\section{ENHANCE ENGAGEMENT}

There is but one political system that is able to rationally and legitimately cope with the divergent political interests affected by climate change and that is democracy. Only a democratic system can sensitively attend to the conflicts within and among nations and communities, decide between different policies, and generally advance the aspirations of different segments of the population. The ultimate and urgent challenge is that of enhancing democracy, for example by reducing social inequality ${ }^{8}$.

If not, the threat to civilization will be much more than just changes to our physical environment. The erosion of democracy is an unnecessary suppression of social complexity and rights.

The philosopher Friedrich Hayek, who led the debate against social and economic planning in the mid-twentieth century ${ }^{9}$, noted a paradox that applies today. As science advances, it tends to strengthen the idea that we should "aim at more deliberate and comprehensive control of all human activities". Hayek pessimistically added: "It is for this reason that those intoxicated by the advance of knowledge so often become the enemies of freedom"10. We should heed his warning. It is dangerous to blindly believe that science and scientists alone can tell us what to do.

Nico Stehr is a sociologist and founding director of the European Center for Sustainability Research at Zeppelin University in Friedrichshafen, Germany. e-mail:nico.stehr@t-online.de

1. Adam, D. The Guardian 'Leading climate scientist: "democratic process isn't working"' (18 March 2009).

2. Beeson, M. Environ. Politics 19, 276-294 (2010)

3. Hansen, J. et al. PLoS ONE http://dx.doi. org/10.1371/journal.pone.0081648 (2013).

4. REN21. Renewables 2015 Global Status Report (REN21, 2015).

5. Runciman, D. The Confidence Trap: A History of Democracy in Crisis from World War I to the Present (Princeton Univ. Press, 2013).

6. Stehr, N. Information, Power and Democracy, Liberty is a Daughter of Knowledge (Cambridge Univ. Press, 2015).

7. Pierre, J. Debating Governance: Authority, Steering, and Democracy (Oxford Univ. Press, 2000).

8. Rosanvallon, P. The Society of Equals (Harvard Univ. Press, 2013).

9. Hayek, F. A. Nature 148, 580-584 (1941).

10. Hayek, F. A. The Constitution of Liberty (Routledge, 1960). 